\title{
An Economic Analysis of the Virtual Water Concept in relation to the Agri-food Sector
}




\section{ORGANISATION FOR ECONOMIC CO-OPERATION AND DEVELOPMENT}

The OECD is a unique forum where the governments of 30 democracies work together to address the economic, social and environmental challenges of globalisation. The OECD is also at the forefront of efforts to understand and to help governments respond to new developments and concerns, such as corporate governance, the information economy and the challenges of an ageing population. The Organisation provides a setting where governments can compare policy experiences, seek answers to common problems, identify good practice and work to co-ordinate domestic and international policies.

The OECD member countries are: Australia, Austria, Belgium, Canada, the Czech Republic, Denmark, Finland, France, Germany, Greece, Hungary, Iceland, Ireland, Italy, Japan, Korea, Luxembourg, Mexico, the Netherlands, New Zealand, Norway, Poland, Portugal, the Slovak Republic, Spain, Sweden, Switzerland, Turkey, the United Kingdom and the United States. The Commission of the European Communities takes part in the work of the OECD.

(C) OECD 2010 


\section{An Economic Analysis of the Virtual Water Concept in relation to the Agri-food Sector}

DENNIS WICHELNS

HANOVER COLLEGE, INDIANA, UNITED STATES OF AMERICA 


\begin{abstract}
Note
This document, An Economic Analysis of the Virtual Water Concept in Relation to the Agri-food Sector, by Dennis Wichelns, of Hanover College, Indiana, is one of the background reports supporting the OECD study (2010) Sustainable Management of Water Resources in Agriculture, which is available at www.oecd.org/water.

The report was carried out under the auspices of the OECD Joint Working Party on Agriculture and the Environment of the Committee for Agriculture and the Environment Policy Committee. The report is published under the responsibility of the author and does not necessarily reflect the views of the OECD or its member countries.
\end{abstract}

The other background reports (also available at www.oecd.org/water) are:

Agriculture's Role in Flood Adaptation and Mitigation - Policy Issues and Approaches Joe Morris, Tim Hess and Helena Posthumus, Cranfield University, United Kingdom http://dx.doi.org/10.1787/786804541573

Environmental Effectiveness and Economic Efficiency of Water Use in Agriculture:

The Experience of and Lessons from the Australian Water Reform Programme

Michael D. Young, University of Adelaide, Australia

http://dx.doi.org/10.1787/786732081512

Financing Water Management and Infrastructure Related to Agriculture across OECD Countries Frank A. Ward, New Mexico State University, United States

http://dx.doi.org/10.1787/786788524232

Agricultural Water Pricing: EU and Mexico

Alberto Garrido, Universidad Politécnica de Madrid; and

Javier Calatrava, Universidad Politécnica de Cartagena, Spain

http://dx.doi.org/10.1787/787000520088

Agricultural Water Pricing in Japan and Korea

James E. Nickum and Chisa Ogura, Asian Water and Resources Institute, Japan

http://dx.doi.org/10.1787/787011574235

Agricultural Water Pricing in Turkey

Erol H. Cakmak, Middle East Technical University, Turkey

http://dx.doi.org/10.1787/787034266022

Agricultural Water Pricing: Australia

Seamus Parker, Council of Mayors (South-East Queensland); and

Robert Speed, Freelance Consultant, Australia

http://dx.doi.org/10.1787/787105123122

Agricultural Water Pricing: United States

Dennis Wichelns, Hanover College, United States

http://dx.doi.org/10.1787/787165082115 


\section{Table of Contents}

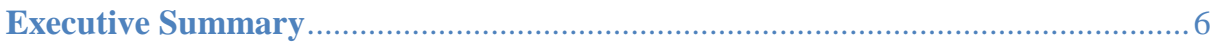

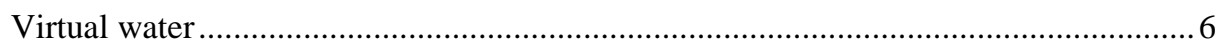

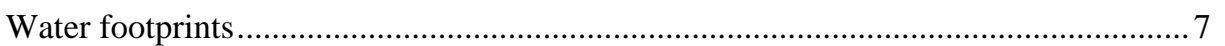

Blue and green components.......................................................................... 7

Economic analysis of the virtual water concept in relation to the agri-food sector 9

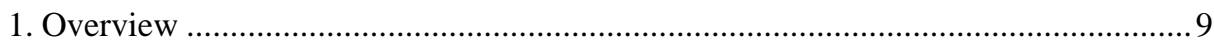

2. Virtual water and water footprints .................................................................. 10

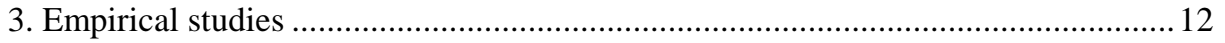

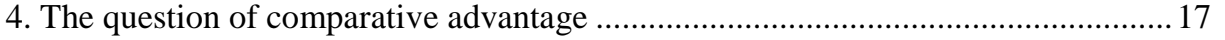

5. A closer look at blue and green ......................................................................... 19

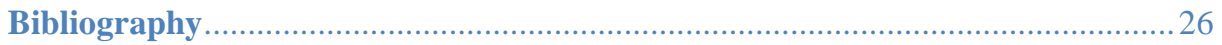




\section{Executive Summary}

\section{Virtual water}

The term "virtual water" began appearing in the water resources literature in the mid-1990s. Professor Tony Allan of London University chose the term to describe the water used to produce crops traded in international markets (Allan 1996, 2002a). During the 15 years since its inception, the virtual water metaphor has been very helpful in gaining the attention of public officials and policy makers responsible for encouraging wise use of limited water resources. The widespread influence and appreciation of the virtual water metaphor are reflected in the awarding of the 2008 World Water Prize to Professor Allan, for his work in proposing and promoting the metaphor in academic and policy discussions. Professor Allan and others who have written about virtual water in recent years have greatly enhanced public awareness of water scarcity and the need for improvements in national and international policies that influence water allocation and water use decisions.

Several authors have conducted empirical analyses of "virtual water flows" between countries, by comparing the water requirements of crops and livestock products involved in international trade. Often the authors conclude that some countries are "net importers of virtual water," while others are "net exporters." Some authors suggest further that, based on the virtual water concept, water-short countries should import water intensive goods and services, while water-abundant countries should export water intensive products. This line of reasoning, while compelling, is not based on a legitimate conceptual framework. Hence, the policy recommendations that follow from this form of virtual water analysis can be incorrect and misleading.

The fundamental shortcoming of the virtual water metaphor that prevents it from serving as a valid policy prescriptive tool is the lack of an underlying conceptual framework. Several authors have incorrectly described virtual water as analogous to, or consistent with the economic theory of comparative advantage. The virtual water metaphor is applied most often when discussing or comparing water-short and water-abundant countries. By focusing on the water resource endowment, alone, virtual water represents an application of absolute advantage, rather than comparative advantage. For this reason, policy prescriptions that arise from virtual water discussions are not those that will maximize the net benefits of engaging in international trade. Comparative advantage is the pertinent economic concept, and virtual water considers only absolute advantage.

Recent empirical analyses of international trade data generally confirm the lack of consistency between virtual water prescriptions and actual trade patterns. Several authors have begun describing the important role of non-water factors in determining optimal production and trading strategies. Several also have begun discussing the limitations of the virtual water metaphor in the context of current policy issues, such as the South-to-North Water Transfer Project in China and the River Linking Program in India. Those authors note the importance of considering population densities, historical production trends, national food security goals, poverty reduction targets, and the availability of complementary inputs when determining whether to transfer water from one region to another, or to achieve desired outcomes alternatively by transporting or trading agricultural commodities. 


\section{Water footprints}

The notion of a water footprint was developed originally as an analogy to the notion of an ecological footprint, which was introduced by Wackernagel and Rees (1996), with the goal of describing the sustainability of a country's rate of consumption of natural resources. In a sense, the ecological footprint is a comprehensive measure of the land, water, and other environmental resources consumed by a population or country (Wackernagel, et al., 1999), while the water footprint measures only the water component of the complete footprint (Chapagain and Hoekstra, 2004a). Estimates of ecological footprints generally account for waste assimilation requirements and are expressed as a measure of land area. Water footprints also account for water used to assimilate pollution, by considering the volume of dilution water required to maintain water quality standards (Hoekstra, 2008, in press).

An important qualitative distinction arises when considering the analogy between ecological and water footprints. Ecological footprints describe the implications of regional or national consumption activities on natural resources and the environment by expressing those impacts in terms of the land area required to support the target population (Wackernagel and Rees, 1996; Wackernagel, et al., 1999; Rees, 2003). Thus ecological footprints enable one to compare the ecosystem implications of consumption activities across regions and countries, and to assess whether a region or country is consuming resources in a sustainable or unsustainable fashion, from a global perspective. Ecological footprint analysis is not sufficient for determining optimal policy alternatives, however, as it does not account for the net benefits generated as resources are consumed.

Water footprints describe the volume of water required to support production and consumption in selected regions or countries. Water is one of many inputs in those activities. Hence, estimated water footprints are somewhat one-dimensional, as they depict the use of only one resource. In addition, water footprints do not describe the implications of water use. Rather, they consider only the amounts of water used in production and consumption activities. Hence, water footprints do not contain sufficient information to evaluate the net benefits generated through the use of water resources.

The costs and benefits of water use depend largely on the opportunity costs of water resources and the ways in which water is combined with other inputs in production and consumption. Water footprints enable one to compare estimated water use, per person or in aggregate across countries, but they are inadequate for evaluating the incremental costs, benefits, or environmental impacts of water use. For this reason, empirical estimates of water footprints do not provide sufficient information for assessing environmental implications or determining policy goals and strategies pertaining to water resources. Like the virtual water metaphor, water footprints bring helpful attention to important policy issues, but they lack the conceptual foundation and breadth required to support policy analysis.

\section{Blue and green components}

Several authors have described the "green" and "blue" components of virtual water and water footprints. "Green water" is used to denote effective rainfall or soil moisture that is used directly by plants, while "blue water" denotes water in rivers, lakes, aquifers, or reservoirs (Falkenmark and Rockström, 2004; Rost et al., 2008). As such, blue water generally refers to water that can be delivered for irrigation or made available for alternative uses, while green water must be used directly from the soil profile.

Like the virtual water metaphor, the blue-green metaphor has helped increase public awareness of an important dimension of water resource management. The terms "green water" and "blue water" generate easily recallable images of soil moisture and stored surface water in a manner that likely is helpful to many public officials and agency staff members. Yet the metaphor does not establish a new conceptual framework that can be used alone to guide policy decisions. Some authors have suggested that the opportunity cost of green water generally is smaller than that of blue water. They propose trading green water for blue water, when possible, to generate meaningful water savings. The perspective regarding opportunity costs is not accurate and the recommendation is not based on a legitimate conceptual framework. 
In summary, the virtual water, water footprint, and blue-green metaphors have brought much-needed attention to important issues regarding water resources, within countries and around the world. These compelling metaphors serve very well in gaining the attention of public officials and policy makers. Current patterns of water allocation and use often reflect underlying market failures that can be corrected with appropriate policy interventions. The metaphors are helpful in bringing attention to these market failures, particularly among members of the media, public officials, and the general public. Yet none of these metaphors is based on an established, underlying conceptual framework, and none is a sufficient criterion for determining optimal policy decisions. Farmers, traders, and public officials must consider many economic and social issues when determining optimal strategies. Virtual water, water footprints, and the blue-green metaphor will be helpful in starting policy discussions in many settings, but they will not be sufficient for determining the optimal outcomes of those discussions. 


\section{Economic Analysis of the Virtual Water Concept in relation to the Agri-food Sector}

\section{Overview}

The goals of this study are to describe and analyze the concept of "virtual water," from an economic perspective, in the context of agricultural production and trade, and to assess the strengths and weaknesses of the concept as a tool that might be used by policy makers. A fair amount of literature on the topic of virtual water has appeared since Professor Tony Allan first proposed the term in the early 1990s. Early articles on the topic describe how water-short countries implicitly import large "volumes" of water in the form of the water required to produce the food grains and other products they import from other countries. The virtual water metaphor has helped bring focus to the important role of international trade in national efforts to maintain food security, particularly in water-short countries.

Since the 1990s, several authors have estimated the "flows of virtual water" between individual countries and around the world, by calculating how much water is used to produce crops in the major exporting countries. The authors multiply estimates of crop water requirements by the amounts of crop and livestock products traded internationally to obtain estimates of "virtual water flows" between countries. The results largely reflect the underlying trade statistics. Major food exporting countries such as Argentina, Australia, Brazil, Canada, Thailand, and the United States are considered to be large exporters of virtual water, while major food importing countries such as China, Egypt, Japan, Russia, South Korea, and the United Kingdom are considered to be large importers of virtual water. There is nothing inherently good or bad about importing or exporting virtual water. The data simply reflect underlying trade patterns, which have evolved over time, for many reasons including natural resource endowments, labor availability, technology, productivity, currency exchange rates, and relative prices.

Some of the authors who have estimated virtual water flows or the amount of "virtual water trading" in the world have suggested that virtual water is analogous to the economic concept of comparative advantage, a fundamental tenet of trade theory. This perspective has encouraged several authors to recommend that countries should apply the virtual water approach in determining optimal production and trading strategies. They suggest that water-short countries should import water-intensive crops and livestock products, while using their limited water resources for higher valued activities. Water abundant countries should produce and export water-intensive products. While compelling at first glance, virtual water is not analogous to comparative advantage, and it cannot serve as a criterion for determining optimal trading strategies.

In recent years, several authors have examined international trade data to determine if the data support the "virtual water hypothesis" that water-short countries should import water-intensive products from water-abundant countries. Results obtained to date generally suggest that international trade data do not reflect national policies that might arise through purposeful implementation of a virtual water strategy. Some of the authors have suggested that other national goals and policy considerations, such as economic growth and development, employment, and food security, might be more important than water scarcity in determining trade patterns. These empirical results are consistent with the conceptual assertion that the virtual water metaphor is not a sufficient criterion for determining optimal national policies regarding water allocation and international trade.

Some of the authors who have published empirical estimates of "virtual water trading" have expanded their analysis to include calculation of "water footprints" that depict the volume of water required to support a country's consumption activities. This idea was generated, in part, by earlier discussions in scholarly literature and the popular press regarding ecological footprints and carbon footprints. The notion of a water footprint is not completely analogous to either of the earlier footprints and the policy relevance of water footprint analysis is limited. Like the virtual water metaphor, water footprints are helpful in bringing attention to an important issue, but they are not helpful in determining optimal policy decisions. 
We seek in this study to enhance public understanding of the usefulness and limitations of the virtual water concept and water footprint analysis. At present there is a notable range of perceptions regarding the pertinent role that virtual water should play in determining optimal water allocations and water use policies in national ministries. Several perspectives have been described over time in the large amount of literature on virtual water and in discussions regarding virtual water in both public and scholarly settings. Water footprint analysis, which is based largely on calculations of virtual water, is gaining the attention of international organizations and policy makers. We endeavor to resolve some of the uncertainty regarding whether or not virtual water and water footprint analysis can be used to guide public policy decisions. We review the literature, describe pertinent economic concepts, and provide several examples that might be helpful in understanding the policy limitations of the virtual water metaphor.

\section{Virtual water and water footprints}

\subsection{Virtual water}

The term "virtual water" began appearing in the water resources literature in the mid-1990s. Professor Tony Allan chose the term to describe the water used to produce crops traded in international markets. Professor Allan noticed during his extensive work in the Middle East and North Africa (MENA) that despite much reference to imminent violent conflict induced by water scarcity, there had been no such conflicts since those of the early 1960s in the Upper Jordan (Allan, 1996, 2002a). Natural water supplies in the region were inadequate to achieve food self-sufficiency. The absence of conflict was explained by the growing reliance of MENA economies on agricultural imports. Large amounts of food grains were imported each year, and the amounts were increasing with population growth. In a sense, the water used to produce imported crops was enabling several water-short countries to achieve food security, even as the water available per person in those countries was declining.

Professor Allan originally used the term "embedded water" to describe the role of imports in achieving food security in water-short countries, but that term did not generate substantial interest in the topic (Allan, 2003). Switching to "virtual water" brought greater attention from public officials, academicians, and other experts. Prof. Allan describes how several water-short countries achieve food security by importing waterintensive food products, rather than producing all of their food supply with limited water resources (Allan, 1998, 2002b). In some countries with large populations and limited resources, substantial amounts of food will need to be imported, in perpetuity, even if all resources are committed to producing food for domestic consumption (Lofgren and Richards, 2003).

Many countries import a large portion of their food supply, whether or not they are explicitly implementing a virtual water strategy (Allan, 2002c; Yang and Zehnder, 2001, 2002). Food imports have enabled several arid countries to maintain national food security as their populations have increased, over time, while their water resource endowments have remained the same. In other countries, the virtual water metaphor might be helpful in describing opportunities for adjusting production and marketing activities in ways that would increase the values generated with limited resources (Wichelns, 2001, 2003).

Interest in the virtual water metaphor increased substantially in the late 1990s and early 2000s, as noted in the literature and in the topics considered at professional meetings (Allan, 1999, 2002c, 2003; Bouwer, 2000, 2002; Earle, 2001; Hoekstra and Hung, 2005; Yang and Zehnder, 2002; Merrett, 2003). The Institute for Water Education at UNESCO-IHE in The Netherlands hosted a meeting of international experts on virtual water in December 2002 (Hoekstra, 2003), and a special session on virtual water was included at the 3rd World Water Forum in Japan in March 2003. An international workshop on virtual water trade was conducted at the German Ministry for Economic Cooperation and Development in Bonn, in December 2005 (Horlemann and Neubert, 2007; Neubert and Horlemann, 2008). The virtual water metaphor now is used widely to describe how water-short countries achieve food security by importing crops and livestock products from water-abundant countries (Yang and Zehnder, 2002; Hoekstra, 2003). 


\subsection{Water footprints}

The water footprint concept was developed originally by some of the same researchers who have promoted empirical application of the virtual water metaphor. Chapagain and Hoekstra (2004a) define the water footprint of a country as "the volume of water needed for the production of the goods and services consumed by the inhabitants of the country." They propose also that the notion of a water footprint is closely linked to the notion of virtual water, which they define as "the volume of water required to produce a commodity or service." Chapagain and Hoekstra (2004a) calculate empirical estimates of water footprints by first estimating the use of domestic water resources and then subtracting "the virtual water flow that leaves the country and add[ing] the virtual water flow that enters the country."

Chapagain and Hoekstra (2004a) distinguish between "internal" and "external" water footprints. "The internal water footprint of a nation is the volume of water used from domestic water resources to produce the goods and services consumed by the inhabitants of the country. The external water footprint of a country is the volume of water used in other countries to produce goods and services imported and consumed by the inhabitants of the country." The sum of the internal and external water footprints is the country's water footprint. Complete estimates of water footprints should include consideration of surface water, groundwater, and soil moisture in agricultural production (Chapagain and Hoekstra, 2004a). An adjustment is made also to account for water quality impacts (Hoekstra, 2008).

Water footprint analysis shares some similarity with life cycle analysis, a methodology adopted originally to describe the complete environmental or ecological impacts of producing and maintaining selected goods and services. Life cycle analysis accounts for the basic resources used to assemble and produce a good, the resources required to maintain the good, and the resources required or impacted upon disposal of the good. For example, life cycle analysis of the environmental impacts of an automobile might include those from producing the aluminum, steel, plastic, and other materials required to build the car, the replacement parts and the tires used to operate and maintain the car, over time, and the environmental impacts of disposing the car at the end of its useful life.

Life cycle analysis is used also to compare the complete range of resources used to produce and utilize a durable good, over time. For example, one might compare the full, life cycle energy costs of using lowenergy and traditional hot water heaters. A low-energy hot water heater generally will require less energy to heat each liter of water. However, its construction might require materials or processing that involve greater energy consumption. Hence, while a traditional heater might consume more energy while in use, the complete life cycle cost of production and use might be smaller than the life cycle cost of a low-energy heater. Similarly, the life cycle financial cost of purchasing and operating a traditional heater can be smaller than the life cycle financial cost for a low-energy heater. For this reason, financial subsidies are sometimes required to promote household adoption of such technological improvements.

Water footprint analysis is similar to life cycle analysis in that both approaches are used to describe impacts on natural resources and the environment. One can calculate water footprints that consider water required only in consumption activities or those that examine all water required in production and consumption. The latter approach begins to resemble the notion of life cycle analysis. For example, the complete water footprint of fish production in rice paddies might include the water required to raise young fish in the nursery and the water used to sustain the aquaculture ponds during production, while accounting also for the water quality impacts of discharging waste water into a receiving stream, lake, or ocean at the end of the production process. The notion of virtual water might enter this analysis if one considers also the water required to produce the fish food and nutrients used in production.

\subsection{Green and blue components}

Several recent descriptions of virtual water and water footprints include discussion of the "green" and "blue" components of those measures. "Green water" is used to denote effective rainfall or soil moisture that is used directly by plants, while "blue water" denotes water in rivers, lakes, aquifers, or reservoirs (Falkenmark and Rockström, 2004; Rost et al., 2008). As such, blue water generally refers to water that can be delivered for irrigation or made available for alternative uses, while green water must be used directly from the soil profile. 
One of the original intents of creating the blue-green metaphor was to emphasize the potential value of utilizing soil moisture in crop production, particularly in rainfed regions and where irrigation largely is supplemental, rather than the only source of water for crop production. Like the virtual water metaphor, the blue-green metaphor, while not establishing a new conceptual framework, has helped increase public awareness of an important dimension of water resource management. The terms "green water" and "blue water" generate easily recallable images of soil moisture and stored surface water in a manner that likely is helpful to many public officials and agency staff members.

\section{Empirical studies}

\subsection{Estimating virtual water flows"}

Several authors have applied the virtual water metaphor empirically in the context of international trade, beginning in the late 1990s and continuing into the early 2000s. Generally, they have estimated the movement of virtual water from one nation to another in traded goods and services. Their calculations of virtual water content have been made from two perspectives: 1) that of the importing country, and 2) that of the exporting country. The first perspective is based on Prof. Allan's original discussion of the virtual water metaphor, in which he describes the political economy of importing food crops, rather than producing them domestically in arid countries (Allan, 1996). In this sense, the importing country is primarily concerned with the volume of water that would have been required to produce the imported corps and livestock products in the absence of trade.

The second perspective is more appropriate when estimating the water footprint of an importing country. The goal of water footprint analysis is to estimate the volume of water used to produce all of the goods and services consumed in a country, including those produced domestically and those imported (Chapagain and Hoekstra, 2004a, 2007; Hoekstra and Chapagain, 2007a, 2007b). The pertinent perspective regarding the virtual water of imported goods in this setting is the volume of water used in the exporting countries. That volume generally is different from the volume that would have been used to produce the goods and services in the importing countries.

Several authors describe the embedded water content of crop and livestock products by accounting for water inputs at various stages of production and processing. They multiply the embedded water coefficients by the amounts of goods and services traded, to estimate the volumes of virtual water moving between nations (Chapagain and Hoekstra, 2003; El Fadel and Maroun, 2003; Hoekstra and Hung, 2002; Hoekstra, 2003; Oki et al., 2003; Zimmer and Renault, 2003). Those estimates are helpful in generating public awareness regarding the volume of water required to support production and consumption activities.

However, policy relevance is gained only by including information regarding the scarcity of water (i.e. its opportunity cost) in a given region or country. Rice production requires large amounts of water, but the opportunity cost of water might be small in humid regions. If the opportunity cost is small, there might be little policy relevance in describing the volume of water embedded in rice or rice products exported from the region. The policy relevance of the virtual water metaphor will be greater where scarcity values (opportunity costs) are substantial.

Some of the authors who have estimated the "flow" of virtual water between countries, and others, have suggested that water-short nations can gain from trade by importing virtual water from nations with larger water endowments (Yang and Zehnder, 2002; Hoekstra and Hung, 2005; Islam et al., 2007; Nassar, 2007; Shuval, 2007, Velázquez, 2007; Chapagain and Hoekstra, 2008). Using the virtual water metaphor in this context has enhanced the discussion of the relationship between water resources and food security. However, the policy relevance of virtual water is limited in some situations, and the policy recommendations that arise in discussions of virtual water often are not consistent with maximizing the value of limited resources. Optimal trading strategies can be determined only by considering the opportunity costs of production within countries, evaluating comparative advantages, and considering other social and economic dimensions of public policy objectives.

Several authors have acknowledged the role of opportunity costs in discussions regarding virtual water. Wichelns (2001) describes virtual water as an application of comparative advantage, with particular emphasis on water resources. Allan (2003) and Lant (2003) mention the theory of comparative advantage in recent discussions of virtual water. Allan (2003) states that "virtual water is something of a descendant 
of the concept of comparative advantage," while Lant (2003) suggests that "like comparative advantage, virtual water is also an application of basic principles of economic geography," which recommend that economic activities requiring inputs with low values per unit of weight should be located close to the sources of those inputs.

Some of the authors who mention comparative advantage suggest that water-short nations should consider importing water-intensive food crops from nations with larger water endowments. That recommendation will be appropriate in some cases, but the underlying conceptual framework is not correct. The virtual water metaphor, when used to describe how a water-short country might gain by importing water-intensive crops, addresses the water endowment of the country, but it does not address comparative advantages. Those can be determined only by considering the resource endowments and the production technologies in two or more countries that can engage in trade.

36. Regarding international trade, it is important to note also that in most trading countries, decisions regarding production, marketing, and trade are made by individual farmers and cooperatives, rather than national governments. Hence it is important to consider comparative advantages at the farm level, rather than at the national level. Institutions governing farm-level access to water, such as water rights, water allocations, and water marketing regimes, are important in determining farm-level comparative advantages. Some farmers in an arid country might have access to a large amount of irrigation water, while others have limited access, as a function of water allocation institutions.

\subsection{Analyzing international trade data}

Questions regarding the policy relevance of the virtual water metaphor have motivated several authors to examine international trade data to determine if the virtual water perspective is helpful in explaining observed patterns of agricultural imports and exports. Some authors test a hypothesis based on international trade theory, while others describe empirical trade patterns in the context of water-short and water-abundant countries.

Earle (2001) posits that the virtual water perspective is based conceptually on the Heckscher-Ohlin model of international trade, which suggests that countries will determine optimal trading strategies based on relative factor endowments. Key assumptions of the model include identical production technologies in trading countries and limited mobility of selected inputs. By imposing identical technologies, the Heckscher-Ohlin model invokes the notion of absolute advantages, rather than comparative advantages, as opportunity costs are the same in trading countries. Despite this less rigorous formulation, which is somewhat consistent with the virtual water perspective, the empirical model performed poorly in predicting trade patterns among the 63 countries in the author's analysis.

Ramirez-Vallejo and Rogers (2004) also examine empirical information within the conceptual framework of the Heckscher-Ohlin model. They, too, find that observed trading patterns are independent of water resource endowments. Further analysis suggests that variables including average income, population, irrigated area, exports of goods and services, and the amount of value added in agriculture are helpful in explaining the observed variation in traded agricultural commodities. Lopez-Gunn and Llamas (2008) also observe that international trade in food is driven largely by factors other than water.

Researchers at the International Water Management Institute have examined the potential impact of international trade on water use, both nationally and globally. They conclude that in 1995, an additional $178 \mathrm{~km}^{3}$ of irrigation water $\left(433 \mathrm{~km}^{3}\right.$ of depleted water) would have been required to produce the 215 million tons of grain that were traded that year, if the grains had been produced domestically in the importing countries (de Fraiture et al., 2004). Accounting for differences in agricultural productivity, the authors conclude that "cereal trade reduces global water use by $164 \mathrm{~km}^{3}$ of crop water (effective rainfall or rainfall plus irrigation) and $112 \mathrm{~km}^{3}$ of irrigation water depletion." Hence in 1995, global water use would have been $6 \%$ higher, and irrigation water depletion would have been $11 \%$ higher, if not for international trade (de Fraiture et al., 2004). The authors caution against inferring that trade will be helpful in mitigating global water scarcity, however, given that water savings cannot always be re-allocated to beneficial uses, and that political and economic considerations might have greater influence than water scarcity in determining national trading strategies. 
Kumar and Singh (2005) also conclude that trading strategies based on the notion of virtual water will not be helpful in mitigating scarcity or improving global water use efficiency. In their analysis of data describing water availability and international trade for 146 countries, the authors find that observed trading patterns are not consistent with those predicted by the virtual water metaphor. Some waterabundant countries import food, while some water-scarce countries export food. The authors conclude that relative land endowments, access to arable land, and water stored in the soil profile would be more helpful than water endowments in explaining the observed variation in international trade patterns.

\section{3. $\quad$ Alternative explanatory variables}

Much of the discussion of virtual water trade has focused on national water endowments as the basis for decisions regarding the importing and exporting of crop and livestock products. This focus is inadequate, in part, because agricultural production requires land and other inputs that also vary among countries in terms of resource endowments, quality, and opportunity cost. As Kumar and Singh (2005) have suggested, access to arable land likely is a better predictor of agricultural trade patterns than a country's water endowment. In particular, countries with less arable land per person are likely to import more crop and livestock products than countries with a larger amount of arable land per person, all else equal. It is helpful to examine these relationships using published data describing water endowments, arable land, and estimates of virtual water trade.

Chapagain and Hoekstra (2004b, Appendix XVIII) present estimates of virtual water imports and exports for many countries. They report estimates pertaining to the trade of crops, livestock, and industrial products. The Food and Agriculture Organization of the United Nations provides estimates of national land and water resource endowments through their FAOSTAT website (www.faostat.fao.org). Graphical analysis of these data provides helpful insight regarding the underlying motivation for trade in crop and livestock products, and the inadequacy of national water endowments as an explanatory variable.

The virtual water hypothesis suggests that water-short countries generally will import water-intensive crop and livestock products, while producing crops that require less water. Furthermore, water-short countries should be described as net importers of virtual water, while water-abundant countries should be described as net exporters. The graphs depicted in Figures 1 through 3 display the estimated net virtual water imports, in $1,000 \mathrm{~m}^{3}$ per person, for 77 of the countries listed in Chapagain and Hoekstra (2005a, Appendix XVIII). The vertical axis, which is the same in each figure, ranges from -4.00 thousand $\mathrm{m}^{3}$ per person to +1.50 thousand $\mathrm{m}^{3}$ per person. Observations above the intercept reflect net virtual water importers, while observations below the intercept reflect net exporters. The data in these figures include only the virtual water pertaining to trade in crop and livestock products. Given the focus of this study on agriculture, data pertaining to virtual water trade in industrial products are not considered. It should also be noted that a country's or a region's water abundance differs from a country's or a region's effective water supply due to spatial and temporal differences in available water.

Figure 1 depicts net virtual water imports as a function of each country's total renewable water resources using water supply data from the FAOSTAT website. Several water-abundant countries appear below the intercept, reflecting their role as exporters of crop and livestock products. Examples include Australia, Canada, New Zealand, Paraguay, and Argentina. Several other water-abundant countries appear above the intercept, suggesting that these countries are net importers of crop and livestock products. Examples in this group include Norway, Papua New Guinea, Peru, Russia, Sweden, and Venezuela. Something other than the national water endowment must be determining their role as net importers of virtual water.

Figure 2 has the same format as Figure 1, but the independent variable is each country's total renewable water resources per hectare of arable land. The data for both the total water resources and arable land are from the FAOSTAT website. Several countries with large water endowments per hectare of arable land are net exporters of virtual water, such as Australia, New Zealand, and Paraguay. Several other countries with large water endowments per hectare are net importers. Those countries include some of the same net importers depicted in Figure 1, such as Norway, Papua New Guinea, Peru, and Venezuela. Singapore also appears as a net importer in Figure 2, despite its water endowment of $750,000 \mathrm{~m}^{3}$ per hectare of arable land. These data suggest that arable land might be a more useful indicator of trade patterns than water endowments. 
Figure 3 depicts the empirical relationship between net virtual water imports and arable land for the same 77 countries as those appearing in Figures 1 and 2. Major exporters of crop and livestock products appear below the axis, as expected. Most net importers of virtual water are characterized by an arable land endowment of less than 0.50 hectares per person. Only one net virtual water importer (Russia) has more arable land per person ( $0.86 \mathrm{ha}$ ). Hence, it is reasonable to state that most net importers of virtual water, as defined by Chapagain and Hoekstra (2004b), have arable land endowments of less than 0.50 hectares per person, and that arable land is a better predictor than water endowment of a country's trade status.

This interpretation of the data presented in Figures 1 through 3 is plausible and consistent with economic theory. Decisions regarding international trade are based on the comparative availability and opportunity cost of many resources and inputs. Water endowments, alone, will not determine international trade patterns. Arable land is a better predictor of trade patterns, in part, because it includes consideration of both land and water availability. Small countries in very humid regions might have large water endowments, but limited land. In countries with large populations, the amount of arable land per person will decline, over time. International trade in crop and livestock products is essential to sustain population growth and enable economic development. Examples of such countries include Indonesia, Japan, Papua New Guinea, and Singapore. Average annual rainfall in these countries ranges from 1.7 meters in Japan to 3.1 meters in Papua New Guinea. Yet all of these countries are net importers of virtual water, largely because their endowments of arable land are not sufficient to support their populations. In summary, focusing on water endowments, alone, neglects the important role of arable land and other inputs in agricultural production and consequent decisions regarding international trade.

Figure 1. Net virtual water imports and renewable water resources

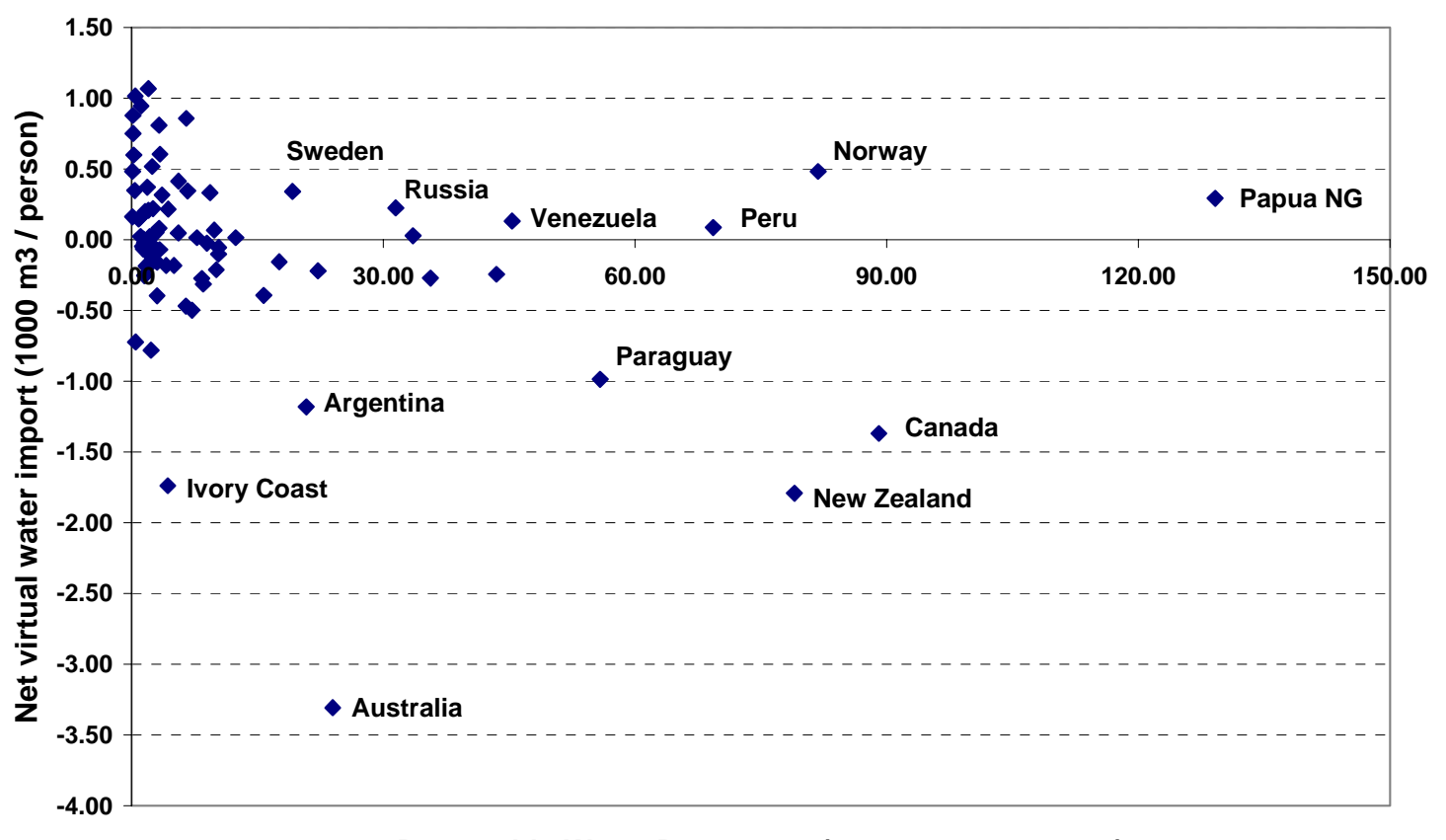

Renewable Water Resources (1000 m3 per person) 
Figure 2. Net virtual water imports and renewable water per hectare

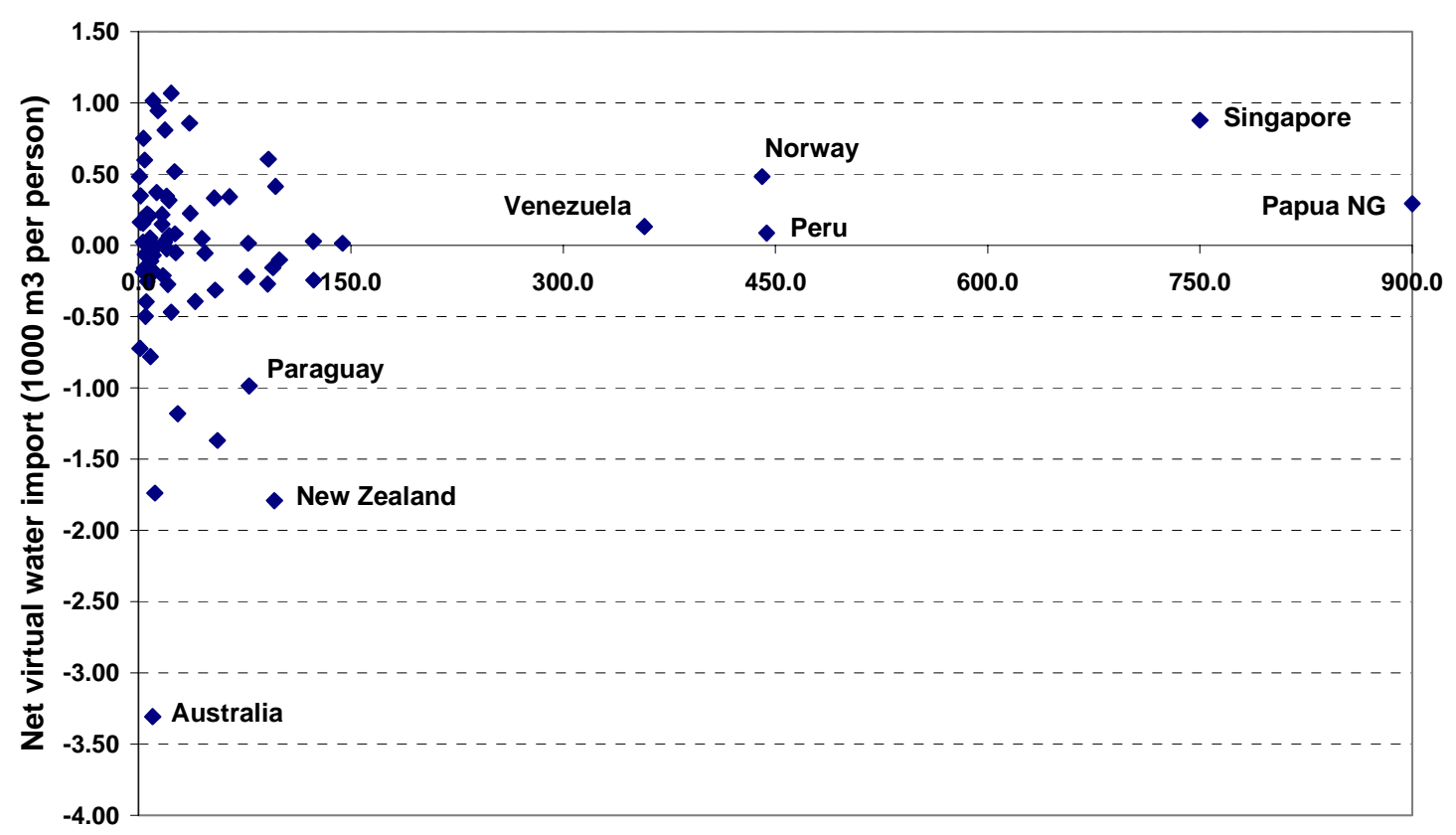

Renewable Water Resources (1000 m3 per hectare)

Figure 3. Net virtual water imports and arable land per person

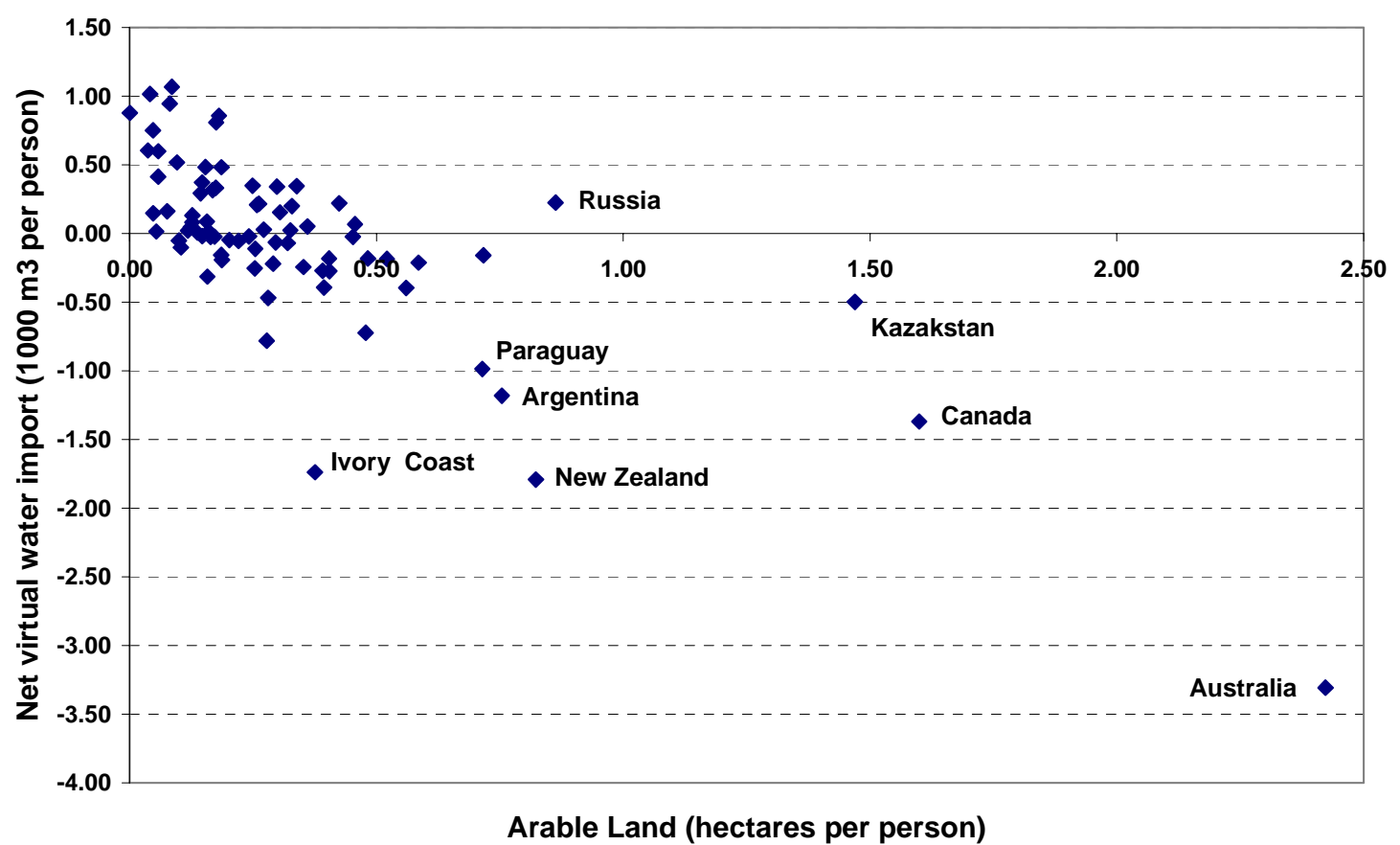




\section{The question of comparative advantage}

\subsection{Conceptual perspective}

The virtual water metaphor was proposed originally to describe a water-short country's strategy, whether implicit or explicit, of importing commodities that require substantial water in production. The focus on international trade has led some authors to describe similarities between the virtual water metaphor and the economic theory of comparative advantage, which is a fundamental component of international trade theory. That observation is enticing but not accurate. The virtual water metaphor is not sufficiently broad in scope to be considered the same concept as comparative advantage. In particular, virtual water discussions and calculations do not consider opportunity costs, which must be considered to determine the optimal allocation of scarce resources (Wichelns, 2004).

The difference between the virtual water metaphor and the economic concept of comparative advantage can be described with examples involving hypothetical countries with different production technologies and resource endowments. Often, the opportunity cost of water will be higher in water-short countries than in water-abundant countries, but that is not always the case. It is easy to construct examples in which the opportunity cost of water is higher in water-abundant countries. Hence a comparison of resource endowments alone, which describes absolute advantage, is not a sufficient criterion for determining optimal trading strategies. Countries must examine their comparative advantages, which involve opportunity costs. Virtual water analysis, which considers only resource endowments and describes absolute advantage, is not a sufficient criterion for optimization.

As noted above, several authors have estimated the embedded water content of crop and livestock products traded in international markets. Often the authors describe the potential gains or savings in water resources made possible by exporting water-intensive products from water-abundant countries to watershort countries. Within this context, some authors have suggested that the virtual water concept is equivalent to, or based upon, the economic concept of comparative advantage. That perspective is not accurate, however, as the discussion of virtual water pertains only to resource endowments, without consideration of opportunity costs. Comparative advantages are determined by examining resource endowments, production technologies, and the opportunity costs of producing tradable commodities within each trading partner. The following examples demonstrate how optimal trading strategies based on comparative advantages can differ notably from recommendations based only on a virtual water perspective.

\subsection{Helpful examples}

Consider two small countries with the same irrigation water endowment of 10 million $\mathrm{m}^{3}$ per year. Suppose each country can produce two crops, cotton and wheat. Suppose also that the irrigation requirements in both countries are $10,000 \mathrm{~m}^{3}$ per ha for cotton and $6,667 \mathrm{~m}^{3}$ per ha for wheat. Given its water endowment, each country could irrigate either 1,000 ha of cotton or 1,500 ha of wheat.

Suppose Country A has good soils, plenty of sunshine, and an adequate supply of crop nutrients. Its production possibilities are 1,200 tons of lint on 1,000 ha of irrigated cotton or 4,800 tons of grain on 1,500 ha of irrigated wheat. Suppose Country B is less productive, due to poorer soils, less sunshine, or inadequate access to crop nutrients. Its production possibilities are 800 tons of lint on 1,000 ha of irrigated cotton or 4,000 tons of grain on 1,500 ha of irrigated wheat. Given these productivity assumptions, Country A can produce more cotton or more wheat than Country B. Hence Country A has an absolute advantage in producing both commodities.

Although Country A has an absolute advantage in both cotton and wheat production, both countries can gain from engaging in trade that is based upon their comparative advantages. The pertinent analysis requires consideration of the opportunity costs of production within each country. For example, Country A must forego producing 4 tons of wheat for each ton of cotton lint it produces. Hence the opportunity cost of producing cotton lint in Country A is 4 tons of wheat. Similarly, the opportunity cost of producing wheat in Country A is 0.25 tons of cotton lint. The same analysis for Country B reveals that the opportunity cost of producing each ton of cotton lint is 5 tons of wheat, and the opportunity cost of producing each ton of wheat is 0.20 tons of cotton. These production possibilities and opportunity costs are summarized in Table 1. 


\section{Table 1.}

Production possibilities for two countries with the same water endowment, but different productivities

\begin{tabular}{|c|c|c|}
\hline & Country A & Country B \\
\hline $\begin{array}{r}\text { Cotton } \\
\text { Wheat }\end{array}$ & 4,200 tons & 800 tons \\
4,800 tons & 4,000 tons \\
\hline $\begin{array}{c}\text { Opportunity Costs } \\
\text { Cotton }\end{array}$ & 4 tons of wheat & 5 tons of wheat \\
Wheat & 0.25 tons of cotton & 0.20 tons of cotton \\
\hline
\end{tabular}

The comparative advantage in each country is determined by examining the opportunity costs depicted in Table 1. Country A has the lower opportunity cost of producing cotton. Hence it has a comparative advantage in cotton production. Similarly, Country B has a comparative advantage in wheat production. Both countries can gain from trade if Country A specializes in cotton production, Country B specializes in wheat production, and the two countries exchange some portion of their output at an agreeable terms of exchange. For example, Country A might send 200 tons of cotton to Country B, in exchange for 880 tons of wheat. The final consumption bundles would include 1,000 tons of cotton and 880 tons of wheat for Country A, and 200 tons of cotton and 3,120 tons of wheat for Country B. It is easy to verify that this trade enables both countries to achieve a consumption bundle that is not achievable in the absence of trade.

The inadequacy of using a virtual water perspective to determine trading strategies can be demonstrated by modifying the irrigation water endowment of Country A. In particular, suppose Country A has only half the water endowment of Country B. Country A could then irrigate only 500 ha of cotton or 750 ha of wheat. Its production possibilities would thus be only 600 tons of cotton lint or 2,400 tons of wheat. While the production possibilities change for Country A, the opportunity costs of production remain the same. Producing one ton of cotton requires Country A to forego producing 4 tons of wheat, just as producing one ton of wheat requires Country A to forego producing 0.25 tons of cotton (Table 2). 
Table 2.

Production possibilities for two countries with different water endowments and different productivities

\begin{tabular}{|r|c|c|}
\hline & Country A & Country B \\
\hline $\begin{array}{r}\text { Cotton } \\
\text { Wheat }\end{array}$ & 2,400 tons & 4,000 tons \\
\hline Opportunity Costs & & \\
Cotton & 4 tons of wheat & 5 tons of wheat \\
Wheat & 0.25 tons of cotton & 0.20 tons of cotton \\
\hline Note: In this example, Country A has one-half the water \\
endowment of Country B.
\end{tabular}

The production possibilities and the opportunity costs remain the same for Country B, which has the same irrigation water endowment as in Example 1. Given this information, Country A retains its comparative advantage in cotton production, while Country B retains its comparative advantage in wheat production. As a result, Country A, which has half the irrigation water endowment of Country B, should specialize in producing cotton, even though cotton has a larger irrigation requirement than wheat.

This optimal trading strategy, which will enable both Countries A and B to gain from trade, is precisely opposite the trading strategy based only on consideration of water endowments. A virtual water perspective would suggest that Country A should specialize in producing wheat, which requires less water per hectare, while Country B should specialize in producing cotton, the water-intensive crop in this example. The problem arises because the virtual water perspective does not consider opportunity costs of production and, hence, it is not equivalent to the economic concept of comparative advantage. The virtual water perspective is not a sufficient criterion for determining optimal trading strategies.

\section{A closer look at blue and green}

\subsection{Conceptual perspective}

Several authors have estimated the blue and green components of virtual water in crops that are traded internationally, noting that most of the virtual water is green rather than blue (Chapagain et al., 2006; Yang et al., 2006; Yang and Zehnder, 2007; Aldaya et al., 2008). This result is expected, as grains and oil crops account for the largest portion of international trade, and most of the traded grains and oil crops are produced in rainfed regions of the major trading countries (Schultz et al., 2005; Liu and Savenije, 2008). Some of the authors have suggested also that "trading green virtual water" is more sensible than "trading blue virtual water" because the opportunity cost of green water is less than that of blue water (Yang et al., 2006; Aldaya et al., 2008). In addition, some authors have suggested that "trading green water for blue water" can generate meaningful water savings from a global perspective. 
These discussions of blue and green virtual water and the implicit policy recommendations need to be evaluated very carefully, given that neither metaphor (virtual water nor blue-green water) is based on an underlying conceptual framework. The blue-green metaphor provides helpful, descriptive terminology, but there is no inherent, underlying principle that can be called upon to suggest optimal production or trading strategies.

Several authors have suggested that the opportunity cost of green water is less than that of blue water (Chapagain et al., 2006; Yang et al., 2006). Some offer the rationale that green water cannot be captured and moved to a higher valued use in the same way that water in a river, aquifer, or canal can be delivered to one or more potential users. Some suggest also that surface water and groundwater often are used to produce higher valued crops, while soil moisture often is used to produce lower valued grains and pasture.

While soil moisture certainly is less mobile and less tradable than surface water or water withdrawn from an aquifer, the assertion regarding a lower opportunity cost is not necessarily accurate or helpful in discussions of trading strategies. At least four points seem pertinent: 1) There is no fundamental principle suggesting that the opportunity cost of soil moisture is always less than the opportunity cost of surface water or groundwater, 2) The incremental value of soil moisture can be quite high in many rainfed situations, 3) The incremental value of surface water or groundwater can be quite low in many irrigated settings, and 4) Relative opportunity costs (comparative advantages), rather than one's own opportunity costs, must be considered to determine optimal trading strategies.

There are many empirical situations in which the incremental value of soil moisture is quite high. Many farmers in rainfed settings depend on effective rainfall for generating the crop yields that provide their livelihoods and ensure their food security. In such settings, farmers might be willing to pay a substantial price for additional soil moisture, if such a market existed. The lack of a market does not preclude the notion of a substantially large incremental value.

The opportunity cost of soil moisture also can be substantial. Although soil moisture cannot be transported for use in an alternative location, the resource can be used in situ to produce any one of several crops. Farmers in rainfed areas might choose to produce grains, vegetables, or fruit crops, depending on market conditions and reasonable expectations regarding the amount and frequency of rainfall. The incremental value and the opportunity cost of soil moisture will vary with the choices available to farmers. For example, the opportunity cost of soil moisture used to produce maize might be the alternative value that could be generated if the soil moisture were used to produce melons. This form of opportunity cost is pertinent when considering the potential gains from trade involving the production decisions of farmers in rainfed areas.

In many irrigated areas, the incremental value and opportunity cost of surface water or groundwater might be smaller than the values implied by some authors. This can occur when the available supply of surface water or groundwater is large, relative to the supply of arable land, and when institutional issues motivate farmers to utilize water themselves, rather than allowing them to lease or sell water to someone who might generate higher incremental values. Farmers with senior water rights might irrigate low-valued grains and pasture, even though someone else might be willing to purchase the water for use in a higher valued activity. The opportunity cost of water in such a situation, from the farmer's perspective, is the incremental value of water in producing the next-best crop.

Given the possible range in incremental values and opportunity costs in rainfed and irrigated areas, it is not accurate to state categorically that economic welfare is enhanced when crops produced in rainfed regions are exported to irrigated regions. Optimal trading strategies can be determined only by examining empirical values of opportunity costs pertaining to each potential trade. A numerical example is helpful in demonstrating the variety of optimal trading strategies that might arise when considering both rainfed and irrigated production. 


\section{2. $\quad$ Helpful example}

Suppose the crop production possibilities and opportunity costs for two countries with rainfed and irrigated areas are those presented in Table 3. Given differences in productivity or the availability of key inputs, Country A can produce more maize and more melons on its rainfed and irrigated land than is possible in Country B. Hence, Country A has an absolute advantage in producing both maize and melons. The empirical values presented in Table 3 are hypothetical, but plausible, regarding potential differences in productivity in rainfed and irrigated settings.

Table 3.

Production possibilities for two countries with rainfed and irrigated agricultural areas

\begin{tabular}{|c|c|c|c|c|}
\hline & \multicolumn{2}{|c|}{ Country A } & \multicolumn{2}{c|}{ Country B } \\
\cline { 2 - 5 } & Rainfed & Irrigated & Rainfed & Irrigated \\
\hline Production Possibilities & & & & \\
Maize & 800 tons & 1,500 tons & 600 tons & 1,200 tons \\
Melons & 4,000 tons & 4,500 tons & 3,600 tons & 4,200 tons \\
\hline Opportunity Costs & & & & \\
Maize & 5 tons of melons & 3 tons of melons & 6 tons of melons & 3.5 tons of melons \\
Melons & 0.20 tons of maize & 0.33 tons of maize & 0.17 tons of maize & 0.29 tons of maize \\
\hline
\end{tabular}

Given the range of opportunity costs shown in Table 3, several types of internal and external trade will expand consumption possibilities in both countries. For example, within either country, in the absence of trade, it would be sensible to specialize in the production of rainfed melons and irrigated maize. If trade is possible, there are several opportunities for increasing consumption possibilities in both countries. For example, Country A might specialize in irrigated maize, while importing rainfed melons from Country B. Alternatively, Country A might specialize in rainfed melons, while importing irrigated maize from Country B. In either of these transactions, the terms of exchange would be determined through negotiations, but would lie somewhere between the opportunity costs in the two countries.

The two countries could gain, also, if Country A were to specialize in irrigated maize production (opportunity cost of 3 tons of melons), while Country B specializes in irrigated melon production (opportunity cost of 0.29 tons of maize). Country A would then send some of its irrigated maize to Country B, in exchange for some of Country B's irrigated melons. The terms of exchange would be determined through negotiations, but would lie somewhere between the opportunity costs in the two countries.

In sum, there are four potential types of trade that would expand consumption possibilities in the two countries (Table 4). Two of the four cases involve exchanges of rainfed and irrigated output, while two cases involve an exchange of either rainfed or irrigated crops. There is not a unique or standard type of trade that will maximize net welfare. As in any trading opportunity, optimal strategies pertaining to rainfed and irrigated production can be determined only by considering comparative advantages, which are determined by evaluating empirical values of the pertinent opportunity costs. 
Table 4.

Welfare enhancing trades pertaining to the countries depicted in Table 3

\begin{tabular}{|lll|}
\hline From Country A & From Country B & Terms of Exchange \\
\hline Irrigated Maize & Rainfed Melons & $\begin{array}{l}\text { Between } 4 \text { and } 6 \text { tons of } \\
\text { melons per ton of maize }\end{array}$ \\
\hline Rainfed Melons & Irrigated Maize & $\begin{array}{l}\text { Between } 0.20 \text { and } 0.29 \text { tons } \\
\text { of maize per ton of melons }\end{array}$ \\
\hline Irrigated Maize & Irrigated Melons & $\begin{array}{l}\text { Between } 0.29 \text { and } 0.33 \text { tons } \\
\text { of maize per ton of melons }\end{array}$ \\
\hline Rainfed Maize & Rainfed Melons & $\begin{array}{l}\text { Between } 5 \text { and } 6 \text { tons of } \\
\text { melons per ton of maize }\end{array}$ \\
\hline
\end{tabular}

6. Policy relevance and implications

\subsection{Conceptual limitations}

Empirical estimates of virtual water and water footprints likely will continue to appear in scholarly literature and the popular press. Some authors will expand the scope of their analysis to include additional countries and regions, while others will improve the accuracy of their measurements by collecting more detailed information regarding water use and production methods. Enhancements in scope and accuracy might increase the attention given to these measures in academic and public policy forums. Yet the public policy value of the virtual water and water footprint metaphors will remain limited, absent a better understanding of the conceptual limitations of these metaphors and the important roles of other factors in determining optimal resource allocation decisions.

In particular, a better understanding of the social, economic, and welfare implications of water allocation decisions is needed. Examining only the water required to produce goods and services generally is insufficient for determining socially optimal policies. As noted above, virtual water is a reflection of absolute advantage, rather than comparative advantage, which requires consideration of opportunity costs. In many applications, pertinent opportunity costs will include implications for labor, livelihoods, food security, environmental amenities, and other considerations that are not reflected in straightforward calculations of crop water requirements. Public officials responsible for policies that influence water allocation must consider a wide range of issues and opportunity costs that are not included within the scope of many virtual water discussions.

Estimates of water footprints share some of the characteristics that limit the policy relevance of virtual water. Primarily, water footprint analysis lacks a supporting conceptual framework. Water footprints describe the volume of water required to support production and consumption in selected regions or countries. Water is one of many inputs in those activities. Hence, estimated water footprints are somewhat one-dimensional, as they depict the use of only one resource. In addition, water footprints do not describe the implications of water use. Rather, they consider only the amounts of water used in production and consumption activities. Hence, water footprints do not contain sufficient information to evaluate the net benefits generated through the use of water resources. 
The costs and benefits of water use depend largely on the opportunity costs of water resources and the ways in which water is combined with other inputs in production and consumption. Water footprints enable one to compare estimated water use, per person or in aggregate across countries, but they are inadequate for evaluating the incremental costs, benefits, or environmental impacts of water use. For this reason, empirical estimates of water footprints do not provide sufficient information for assessing environmental implications or determining policy goals and strategies pertaining to water resources.

Like the virtual water metaphor, water footprints bring helpful attention to important policy issues, but they lack the conceptual foundation and breadth required to support policy analysis. For example, Nazer et al. (2008) estimate the water footprint of Palestinians in the West Bank to be 2,791 million $\mathrm{m}^{3}$ per year. The consumption portion of the water footprint is $1,116 \mathrm{~m}^{3}$ per person, per year, which the authors suggest is indicative of severe water scarcity. This estimate is informative and brings attention to water resource issues in the region. However, the water footprint, alone, does not provide guidance to national or regional public officials regarding policies that might be implemented to alleviate the water shortage in the near term or over time.

Chapagain et al. (2006) provide detailed estimates of the water footprints of cotton consumption in many countries. They estimate that cotton consumption is responsible for $2.6 \%$ of global water use, and that $44 \%$ of the water used for cotton production and processing supports export markets, rather than domestic markets. The authors then suggest that "nearly half the water problems in the world related with cotton growth and processing can be attributed to foreign demand for cotton products." The conceptual support for such a statement is not evident. The estimated water footprints describe only the volumes of water used in cotton production and processing. They do not provide information or insight regarding the implications of water use in either the importing or exporting countries.

Hoekstra and Chapagain (2007a) note the limited scope of water footprint analysis in the discussion portion of their report on water footprints in Morocco and the Netherlands. The authors present their results as "analytical fact[s] without the intention to suggest that the virtual water flows revealed are good (e.g., because [they are] economically efficient or because [they save] water resources) or bad (e.g., because [they create] dependence or because [they externalize the] negative effects of water use without [compensation]." Indeed, water footprint analysis considers only water volumes and does not provide information describing the social or economic implications of water use in either the importing or exporting countries. Hence water footprint analysis has limited usefulness in answering key policy questions.

\section{2. $\quad$ Current policy issues}

Some authors of recent literature have begun describing with greater clarity how factors other than water influence optimal national strategies regarding water resources. While acknowledging that water scarcity is a critical issue that motivates governments to implement aggressive programs, they describe also the broader sets of goals and constraints that influence policy decisions.

Belloumi and Matoussi (2008) reflect this perspective in their analysis of issues that determine optimal trading strategies, particularly in the Middle East and North Africa. The authors note that arid nations in the region must continue to import large amounts of food to satisfy domestic demands, while farmers will seek opportunities to increase their incomes by focusing on higher valued fruits and vegetables. Access to markets in Europe, rising demands from China and India, climate change, and changes in energy prices likely will have greater impacts on trade patterns and the terms of trade in the region, than issues regarding water scarcity alone.

El-Fadel and Maroun (2003) reach a similar conclusion regarding optimal water management in Lebanon. They note that while Lebanon is a potential exporter of virtual water to other countries in the Middle East, the country currently imports substantial volumes of virtual water in agricultural crops. The authors suggest that Lebanon must consider several non-water issues, such as national security, food security, economic growth, and the quality of life of its citizens very carefully, before choosing a strategy that would change its status from a virtual water importer to a virtual water exporter.

Several authors have examined or discussed the issue of virtual water in the context of water allocation and inter-regional trade within China. Berkoff (2003) suggests that China might justify the large cost of its South-to-North Water Transfer Project in part by citing concerns regarding national food security and the large number of residents employed in agriculture on the North China Plain. Ma et al. 
(2006) also examine commodity trade between south and north China, suggesting that in 1999 northern China exported 52 billion $\mathrm{m}^{3}$ of virtual water in the crops it sent to southern China. The authors note that this volume is larger than the proposed annual transfer of 38 billion $\mathrm{m}^{3}$ of water from southern to northern China when the project is completed. Given the potential environmental implications of the transfer project, the authors suggest that considerations other than water resources must be guiding the decision to move so much water from southern to northern China.

Guan and Hubacek (2007) examine the current movement of agricultural products between northern and southern China, with the goal of determining whether or not the data reflect implementation of a virtual water trading strategy. Their null hypothesis is that water-scarce northern China will import waterintensive goods and export goods requiring less water in production, while water-abundant southern China will operate in reverse. The data do not support the "virtual water hypothesis." Water-scarce northern China exports a range of water-intensive goods and services, while water-abundant southern China imports water-intensive goods. The authors suggest that several factors influencing agricultural input use and productivity - water price, labor availability, and soil and land quality - might be responsible for the results they have observed. Indeed, these factors are among those that help determine opportunity costs and enable one to consider comparative advantages.

Dabrowski et al. (2008) examine agricultural trade data for the 14 member countries of the Southern African Development Community (SADC), for the purpose of determining net movements of virtual water among countries. South Africa is the largest producer and exporter of maize in the region, even though it is a relatively water-short country. Zimbabwe and Zambia are the largest importers of maize in the region, even though both countries receive more rainfall, on average, than South Africa. Average yields of maize are higher in South Africa than in all other SADC countries, with the exception of Mauritius. Hence, South Africa produces more maize per unit of water consumed than in most other SADC countries. Dabrowski et al. (2008) conclude that agricultural trade in the region is driven by crop productivity, rather than water scarcity.

\section{3. $\quad$ A view to the future}

Discussions of virtual water and water footprints likely will arise often in future, in discussions of international trade and in analyses of large-scale, complex water transfer projects, such as China's Southto-North Water Transfer Project and India's River Linking Project. Some authors will propose utilizing international trade to alleviate national or regional water shortages, while others will suggest that other national issues and goals might limit reliance on international trade. Similarly, some authors will recommend moving forward with water transfer projects, while others might recommend transferring virtual water in the form of crops, within countries, rather than transferring actual water resources. Much of the discussion and the resulting policy options can be enhanced by thoughtful consideration of the limitations of helpful metaphors in policy analysis.

Initial discussions that exemplify this approach include those by Berkoff (2003) and Ma et al. (2006) regarding the South-to-North Water Transfer Project in China. Those authors acknowledge the concept of virtual water, while also considering a broader range of policy goals and implications. Gupta and Deshpande (2004) and Kumar and Jain (2007) examine virtual water strategies within the context of India's increasing population and the challenge of meeting its increasing food demands from now through 2050. They note that determining the optimal transfer of water resources and the movement of agricultural goods within India, and selecting the country's optimal trading strategy will require broader analysis than is possible by considering only the notion of virtual water.

Gupta and van der Zaag (2008) propose five criteria for evaluating interbasin water transfers in India: 1) evaluating real and perceived water deficits, 2) providing good governance, 3) protecting water rights, 4) considering sound science (hydrology, ecology, socio-economics), and 5) ensuring sustainability. These items include a much broader scope of issues than those that are apparent within a virtual water perspective. Verma et al. (2008) also recommend consideration of non-water factors in determining India's optimal water resource strategy. They suggest that the current situation in which a few states produce large portions of India's food supply and, thus, export large amounts of virtual water to other states, is not optimal. In their view, India's National River Linking Program might provide socioeconomic benefits that are not evaluated within the context of virtual water analysis. 
Roth and Warmer (2008) also expand the discussion of virtual water in a helpful manner by describing the political and economical implications of state-level and national water resource strategies. They note that virtual water strategies influence real water resources and livelihoods in ways that often are similar to the implications of infrastructure projects that enable the interbasin transfer of physical water resources. Horlemann and Neubert (2007) also provide insightful discussion of the social, political, and economic dimensions of virtual water trading. They describe several challenges that might limit the ability of some countries to implement virtual water strategies, such as the potential risk of losing food sovereignty, the lack of markets for non-food crops, and inadequate infrastructure in rural areas. The authors suggest that improvements in water management practices might be more helpful than implementing virtual water trading strategies in some countries.

These recent studies of current water resource issues provide hopeful signs that much of the future discussion of virtual water and water footprints will include broader consideration of policy goals, constraints, complementary inputs, and opportunity costs. One goal of such improvement in the discourse might be considered as determining how to utilize the attractiveness and compelling nature of the virtual water and water footprint metaphors as starting points for enhancing public interest in water resource issues, while not relying on virtual water discussions alone to guide public policy decisions. Since the mid1990s, these metaphors have generated notable public attention and interest in one of the world's most important, yet limited, resources. As a result, the current outlook for informed policy discourse in the water sector is much brighter than in might have been. The key to moving forward effectively is to broaden the scope and depth of policy discussions by first acknowledging the inherent limitations of the metaphor, and then demonstrating the value of analysis based on a rigorous conceptual framework and implemented using a larger set of pertinent variables. Wiser policies and greater social benefits will result from such efforts.

The public awareness value of the virtual water and water footprint metaphors likely will gain importance in future, as water scarcity increases in many areas. Residents of countries in which aquifers are being over-pumped in unsustainable fashion or the flows of key rivers are being diminished persistently by diversions for irrigation likely will gain interest in the long-term implications of domestic water policies. Given the increasing media coverage of global water scarcity issues and the potential implications of climate change, many residents might gain interest also in regional and national patterns of agricultural production and international trade in goods and services. The virtual water and water footprint metaphors will continue to enhance public awareness of these issues. A broader understanding of the limitations of the metaphors from a public policy perspective will enhance the discussion of meaningful policy alternatives. 


\section{Bibliography}

Aldaya, M.M., Hoekstra, A.Y., Allan, J.A., 2008. Strategic importance of green water in international trade. Value of Water Research Report Series Number 25, UNESCO-IHE Institute for Water Education, Delft, the Netherlands.

Allan, J.A., 1996. Water use and development in arid regions: Environment, economic development and water resource politics and policy. Review of European Community and International Environmental Law 5(2): 107-115.

Allan, J.A., 1998. Virtual water: a strategic resource. Global solutions to regional deficits. Ground Water 36(4): 545-546.

Allan, J.A., 1999. Global systems ameliorate local droughts: water, food and trade. School of Oriental and African Studies, University of London.

Allan, J.A., 2002a. Hydro-peace in the Middle East: Why no water wars? A case study of the Jordan River Basin. SAIS Review 22(2): 255-272.

Allan, J.A., 2002b. The Middle East Water Question: Hydropolitics and the Global Economy. L.B. Tauris Publishers, London.

Allan, J.A., 2002c. Water resources in semi-arid regions: real deficits and economically invisible and politically silent solutions. In: Turton, A., Henwood, R. (Eds.), Hydropolitics in the Developing World: a Southern African Perspective. African Water Issues Research Unit, University of Pretoria, South Africa.

Allan, J.A., 2003. Virtual water - the water, food, and trade nexus: Useful concept or misleading metaphor? Water International 28(1): 4-11.

Belloumi, M., Matoussi, M.S., 2008. Water scarcity management in the MENA region from a globalization perspective. Development 51(1): 135-138.

Berkoff, J., 2003. China: The South-North Water Transfer Project - Is it justified? Water Policy 5: 1-28.

Bouwer, H., 2000. Integrated water management: emerging issues and challenges. Agricultural Water Management 45(3): 217-228.

Bouwer, H., 2002. Integrated water management for the 21st century: problems and solutions. Journal of Irrigation and Drainage Engineering 128(4): 193-202.

Chapagain, A.K., Hoekstra, A.Y., 2003. Virtual water trade: a quantification of virtual water flows between nations in relation to international trade of livestock and livestock products. In: Hoekstra, A.Y. (Ed.), Virtual Water Trade: Proceedings of the International Expert Meeting on Virtual Water Trade, Research Report Series No. 12. IHE Delft, The Netherlands.

Chapagain, A.K., Hoekstra, A.Y., 2004a. Water Footprints of Nations, Volume 1: Main Report. Value of Water Research Report Series No. 16, UNESCO-IHE Institute for Water Education, Delft, The Netherlands.

Chapagain, A.K., Hoekstra, A.Y., 2004b. Water Footprints of Nations, Volume 2: Appendices. Value of Water Research Report Series No. 16, UNESCO-IHE Institute for Water Education, Delft, The Netherlands. 
Chapagain, A.K., Hoekstra, A.Y., 2006. Water saving through international trade of agricultural products. Hydrology and Earth System Sciences 10(3): 455-468.

Chapagain, A.K., Hoekstra, A.Y., 2007. The water footprint of coffee and tea consumption in the Netherlands. Ecological Economics 64(1): 109-118.

Chapagain, A.K., Hoekstra, A.Y., 2008. The global component of freshwater demand and supply: An assessment of virtual water flows between nations as a result of trade in agricultural and industrial products. Water International 33(1): 19-32.

Chapagain, A.K., Hoekstra, A.Y., Savenije, H.H.G., Gautam, R., 2006. The water footprint of cotton consumption: An assessment of the impact of worldwide consumption of cotton products on the water resources in the cotton producing countries. Ecological Economics 60(1): 186-203.

Dabrowski, J.M., Masekoameng, E., Ashton, P.J., 2008. Analysis of virtual water flows associated with the trade of maize in the SADC region: Importance of scale. Hydrology and Earth System Sciences Discussions, 5: 2727-2757.

De Fraiture, C., Cai, X., Amarasinghe, U., Rosegrant, M., Molden, D., 2004. Does international cereal trade save water? The impact of virtual water trade on global water use. Comprehensive Assessment Research Report 4, International Water Management Institute, Colombo, Sri Lanka.

Earle, A., 2001. The role of virtual water in food security in Southern Africa. Occasional Paper No. 33, School of Oriental and African Studies, University of London.

El Fadel, M., Maroun, R., 2003. The concept of 'virtual water' and its applicability in Lebanon. In: Hoekstra, A.Y. (Ed.), Virtual Water Trade: Proceedings of the International Expert Meeting on Virtual Water Trade, Research Report Series No. 12. IHE Delft, The Netherlands.

Falkenmark, M., Rockström, J., 2004. Balancing Water for Humans and Nature, Earthscan Publications, London.

Guan, D., Hubacek, K., 2007. Assessment of regional trade and virtual water flows in China. Ecological Economics 61(1): 159-170.

Gupta, J., van der Zaag, P., 2008. Interbasin water transfers and integrated water resource management: Where engineering, science and politics interlock. Physics and Chemistry of the Earth 33(1-2): 28-40.

Gupta, S.K., Deshpande, R.D., 2005. Water for India in 2050: First-order assessment of available options. Current Science 86(9): 1216-1224.

Hoekstra, A.Y. (Ed.), 2003. Virtual water trade: Proceedings of the International Expert Meeting on Virtual Water Trade. Value of Water Research Report Series No. 12, UNESCO-IHE, Institute for Water Education, Delft, The Netherlands.

Hoekstra, A.Y., 2008. Water Neutral: Reducing and Offsetting the Impacts of Water Footprints. Value of Water Research Report Series No. 28, UNESCO-IHE Institute for Water Education, Delft, The Netherlands.

Hoekstra, A.Y., Chapagain, A.K., 2007a. The water footprints of Morocco and the Netherlands: Global water use as a result of domestic consumption of agricultural commodities. Ecological Economics 64(1): 143-151.

Hoekstra, A.Y., Chapagain, A.K., 2007b. Water footprints of nations: Water use by people as a function of their consumption pattern. Water Resources Management 21(1): 35-48.

Hoekstra, A.Y., in press. Human appropriation of natural capital: A comparison of ecological footprint and water footprint analysis. Ecological Economics, forthcoming.

Hoekstra, A.Y., Hung, P.Q., 2002. Virtual water trade: a quantification of virtual water flows between nations in relation to international crop trade. Research Report Series No. 11. IHE Delft, The Netherlands.

Hoekstra, A.Y., Hung, P.Q., 2005. Globalisation of water resources: International virtual water flows in relation to crop trade. Global Environmental Change 15(1): 45-46. 
Horlemann, L., Neubert, S., 2007. Virtual water trade: A realistic concept for resolving the water crisis? German Development Institute Report Number 25, Bonn, 118 pages.

Islam, M.S., Oki, T., Kanae, S., Hanasaki, N., Agata, Y., Yoshimura, K., 2007. A grid-based assessment of global water scarcity including virtual water trading. Water Resources Management 21(1): 19-33.

Kumar, M.D., Singh, O.P., 2005. Virtual water in global food and water policy making: Is there a need for rethinking. Water Resources Management 19(6): 759-789.

Kumar, V., Jain, S.K., 2007. Status of virtual water trade from India. Current Science 93(8): 1093-1099.

Lant, C., 2003. Commentary. Water International 28(1): 113-115.

Liu, J., Savenije, H.H.G., 2008. Food consumption patterns and their effect on water requirement in China. Hydrology and Earth System Sciences 12(3): 887-898.

Lofgren, H., Richards, A., 2003. Food security, poverty, and economic policy in the Middle East and North Africa. In: Lofgren, H. (Ed.), Food, Agriculture, and Economic Policy in the Middle East and North Africa, Vol. 5. pp. 1-31.

Lopez-Gunn, E., Llamas, M.R., 2008. Re-thinking water scarcity: Can science and technology solve the global water crisis? Natural Resources Forum 32(3): 228-238.

Ma, J., Hoekstra, A.Y., Wang, H., Chapagain, A.K., Wang, D., 2006. Virtual versus real water transfers within China. Philosophical Transactions of the Royal Society B 361: 835-842.

Merrett, S., 2003. Virtual water and Occam's razor. Water International 28(1): 103-115.

Nassar, Y.H., 2007. Virtual water trade as a policy instrument for achieving water security in Palestine. In: Shuval, H., Dweik, H. (Eds.) Water Resources in the Middle East: Palestinian Water Issues From Conflict to Cooperation. Springer-Verlag, Berlin.

Nazer, D.W., Siebel, M.A., Van der Zaag, P., Mimi, Z., Gijzen, H.J., 2008. Water footprint of the Palestinians in the West Bank. Journal of the American Water Resources Association 44(2): 449-458.

Neubert, S., Horlemann, L., 2008. Strategic virtual water trade - A critical analysis of the debate. In: Scheumann, W., Neubert, S., Kipping, M. (Eds.) Water Politics and Development Cooperation: Local Power Plays and Global Governance. Springer-Verlag, Berlin.

Oki, T., Sato, M., Kawamura, A., Miyake, M., Kanae, S., Musiake, K., 2003. Virtual water trade to Japan and in the world. In: Hoekstra, A.Y. (Ed.), Virtual Water Trade: Proceedings of the International Expert Meeting on Virtual Water Trade, Research Report Series No. 12. IHE Delft, The Netherlands.

Ramirez-Vallejo, J., Rogers, P., 2004. Virtual water flows and trade liberalization. Water Science \& Technology 49(7): 25-32.

Rees, W.E., 2003. A blot on the land. Nature 421: 898.

Rost, S., Gerten, D., Bondeau, A., Lucht, W., Rohwer, J., Schaphoff, S., 2008. Agricultural green and blue water consumption and its influence on the global water system. Water Resources Research 44(9): 17 pages.

Roth, D., Warner, J., 2008. Virtual water: Virtuous impact? The unsteady state of virtual water. Agriculture and Human Values 25(2): 257-270.

Schultz, B., Thatte, C.C., Labhsetwar, V.K., 2005. Irrigation and drainage: Main contributors to global food production. Irrigation and Drainage 54(3): 263-278.

Shuval, H., 2007. 'Virtual Water' in the water resource management of the arid Middle East. In: Shuval, H., Dweik, H. (Eds.) Water Resources in the Middle East: Palestinian Water Issues - From Conflict to Cooperation. Springer-Verlag, Berlin.

Velázquez, E., 2007. Water trade in Andalusia. Virtual water: An alternative way to manage water use. Ecological Economics 63(1): 201-208.

Verma, S., Kampman, D.A., van der Zaag, P., Hoekstra, A.Y., 2008. Going against the flow: A critical analysis of inter-state virtual water trade in the context of India's National River Linking Program. Physics and Chemistry of the Earth, forthcoming. 
Wackernagel, M., Onisto, L., Bello, P., Linares, A.C., Falfán, I.S.L., Garcia, J.M., Guerrero, A.I.S., Guerrero, M.G.S., 1999. National natural capital accounting with the ecological footprint concept. Ecological Economics 29(3): 375-390.

Wackernagel, M., Rees, W., 1996. Our Ecological Footprint: Reducing Human Impact on the Earth. New Society Publishers. Gabriola Island, B.C., Canada.

Wichelns, D., 2001. The role of 'virtual water' in efforts to achieve food security and other national goals, with an example from Egypt. Agricultural Water Management 49(2): 131-151.

Wichelns, D., 2003. The role of public policies in motivating virtual water trade, with an example from Egypt. In: Hoekstra, A.Y. (Ed.), Virtual Water Trade: Proceedings of the International Expert Meeting on Virtual Water Trade, Research Report Series No. 12. IHE Delft, The Netherlands.

Wichelns, D., 2004. The policy relevance of virtual water can be enhanced by considering comparative advantages. Agricultural Water Management 66(1): 49-63.

Yang, H., Wang, L., Abbaspour, K.C., Zehnder, A.J.B., 2006. Virtual water trade: An assessment of water use efficiency in the international food trade. Hydrology and Earth System Sciences 10(3): 443454.

Yang, H., Zehnder, A., 2001. China's regional water scarcity and implications for grain supply and trade. Environmental Planning A 33: 79-95.

Yang, H., Zehnder, A.J.B., 2002. Water scarcity and food import: A case study for southern Mediterranean countries. World Development 30(8): 1413-1430.

Yang, H., Zehnder, A., 2007. "Virtual water:" An unfolding concept in integrated water resources management. Water Resources Research 43(12): 1-10.

Zimmer, D., Renault, D., 2003. Virtual water in food production and global trade: review of methodological issues and preliminary results. In: Hoekstra, A.Y. (Ed.), Virtual Water Trade: Proceedings of the International Expert Meeting on Virtual Water Trade, Research Report Series No. 12. IHE Delft, The Netherlands. 